\title{
Nutritional and Anthropometric Analysis of Edentulous Patients Wearing Implant Overdentures or Conventional Dentures
}

\author{
Katia MULLER ${ }^{1}$ \\ José MORAIS ${ }^{2}$ \\ Jocelyne FEINE ${ }^{1}$ \\ ${ }^{1}$ Faculty of Dentistry, McGill University, Montreal, Quebec, Canada \\ ${ }^{2}$ McGill Nutrition and Food Science Centre, McGill University Health Centre, \\ Royal Victoria Hospital, Montreal, Quebec, Canada
}

\begin{abstract}
As masticatory efficiency diminishes drastically in edentulous patients, several researchers have studied over the past two decades how dietary intake varies when different types of oral rehabilitation are provided. Since the use of implants to support prostheses in edentulous mandibles has been shown to significantly improve masticatory performance, the question remains as to whether this improvement will influence the nutritional status. The purose of this study was to evaluate the nutritional status of edentulous patients who randomly received either a mandibular conventional denture (CD) or an implant-supported overdenture (IP) 1 year previously. Weight, height, body composition and handgrip strength measurements were collected for analysis. Blood tests were performed to measure plasma parameters of diet intake. Participants responded to a Food Frequency Questionnaire and a Masticatory Function Questionnaire. Fifty-three people participated (58\% men, 42\% women; mean age $=53$ ). Body composition indicators as well as plasma parameters were generally within normal range, and no statistically significant difference ( $>0.05)$ was found between the groups. Patients in the CD group had significantly lower ratings for items regarding difficulty in chewing ( $\mathrm{p}<0.05)$, but no significant difference was found for dietary intake $(\mathrm{p}>0.05)$. Although the $\mathrm{CD}$ wearers reported having more difficulty in chewing hard foods, both groups appeared to have a similar nutritional status.
\end{abstract}

Key Words: implant-supported overdentures, complete dentures, nutritional status.

\section{INTRODUCTION}

Thirty years ago in the USA approximately $41 \%$ of the population over 65 years old had lost all teeth (1). Since then, a marked decrease in edentulism has occurred in many western countries. In spite of that, the rates of edentulism in Quebec, Canada, have been reported as being $15 \%$ for the 35-44-year-old, $22 \%$ for the 45-54-year-old, 37\% for the 55-64-year-old age ranges, and $58 \%$ for the population over 65 years (2). Moreover, the elderly segment of the American society has grown faster than any other age group. It has increased from 4.9 million in 1900 to nearly 29.1 million in 1985, and this group is expected to represent $20 \%$ of the total population in 2020. Based on these rates, it may be inferred that the demand for treatment of the edentulous jaw will continue for many in Canada, as well as in several developing countries worldwide (3).

With the increased interest in the role of specific nutrients in the pathogenesis of common age-related diseases, the nutrient content of the diet of edentulous people with different types of oral rehabilitation is of particular concern. Furthermore, a large number of these older adults have healthy and active post-retirement lives and they expect social pleasures to continue throughout advanced life. The ability to eat comfortably with others and to be free from pain and oral problems that may cause embarrassment is an important part of healthy aging. Therefore, the demand for more complex dental services to meet the needs and expectations of 
this population is increasing.

The mouth is the usual pathway for nourishment. Pain from irritated gingiva or chewing difficulties due to ill-fitting dentures may profoundly influence one's desire and ability to eat properly. It has been suggested that these factors can lead to an unbalanced diet and deficient nutrient intake (4-6). However, it has been shown that a good chewing ability is not essential for good nutrition and that improvement in masticatory function does not seem to change dietary intake patterns $(7,8)$.

Studies have shown a high prevalence of patients receiving new and technically well-made dentures who are generally satisfied with the treatment (9). However, clinical experience confirms the existence of a large number of patients with "varying degrees" of prosthetic success and a smaller number with no success at all. The outcomes used to assess the problem include patient satisfaction, absence of pain, esthetics and masticatory ability (10) and, although the conventional removable denture reduces the disabilities and handicaps of edentulism, it certainly does not fully meet the needs of all patients. Therefore, the purpose of this study was to compare the nutritional status of patients who had randomly received either a mandibular conventional denture or an overdenture supported by two endosseous implants 1 year previously. In a 2-month postdelivery assessment, the implant group had given significantly higher ratings on ease of chewing (11). A multidimensional approach was used to assess the nutritional status, including a food-frequency questionnaire, anthropometric and body composition measurements and biochemical parameters. Patients' impressions about the quality of their masticatory function were also assessed using a self-administered questionnaire.

\section{MATERIAL AND METHODS}

\section{Patient Recruitment}

The patients who participated in the present study were previous participants of a randomized clinical trial that compared mandibular conventional dentures and overdenture supported by two endosseous implants with a connecting bar (11). For the previous study, all subjects were edentulous, aged 35 to 65 years and responded to an advertisement in a French newspaper targeting individuals interested in the replacement of their complete dentures. The inclusion criteria specified that subjects must had been edentulous for at least 10 years and must had been wearing their conventional dentures regularly.

For the present investigation, a research assistant contacted by telephone the 102 patients who had participated in the previously described randomized clinical trial and 53 subjects agreed to participate. Patients were scheduled for an appointment at the Royal Victoria Hospital in Montreal, Canada, where they read and signed an informed consent form approved by the McGill University Research Ethics Committee.

\section{Laboratory Analysis}

Each subject had $50 \mathrm{cc}$ of venous blood drawn from an antecubital vein, which was immediately taken to the hospital's laboratory for analysis. The laboratory profile included complete blood count for hemoglobin level, red blood cell indices and lymphocyte count, serum levels of albumin, ferritine and carotene, and plasma levels of vitamin $B_{12}$ and folic acid.

\section{Anthropometric Measures}

Body weight and body height were neasured. Body mass index (BMI) was expressed as $\mathrm{kg} / \mathrm{m}^{2}$.

\section{Body Composition Assessment}

Circumference measurements of the arm, chest, smallest waist, umbilical waist, hip and thigh were taken with non-elastic tape, and skinfold thickness of triceps, biceps, subscapular, suprailiac and umbilical areas were measured with a Lange caliper according to standardized techniques. The sum of the above first four skinfold thickness measurements was used to estimate \% body fat. Lean body mass (LBM) was calculated by subtracting body fat mass from body weight.

\section{Dietary Intake Assessment}

Usual dietary intake of calories, protein and micronutrients was assessed with the Willett foodfrequency questionnaire (12). A specified portion size from all food-groups is listed and participants are asked to indicate how often they consume that amount. This questionnaire includes information on the type of food and its preparation method. In addition, it provides the 
option for open-ended additions to the standard food list. The Willett food-frequency questionnaire recorded dietary information over the previous 12-month period. The subjects then answered a self-administered questionnaire measuring the self impression on the quality of masticatory function (QMF) (Fig. 1). This instrument, which is originally written in French, consists of 29 questions related to frequency and difficulty chewing different types of foods in the previous 2 weeks, and has 5 Likert-response options ranging from "always" to "never" or "a lot" to "no difficulty", and has been previously used in similar studies $(11,13)$.

\section{Statistical Analysis}

The analysis of the data collected for the nutri- tional assessment was performed using the SPSS statistical software for MS Windows (SPSS Inc., Chicago, IL, USA). Differences in means between the two groups of patients were analyzed by ANOVA for body circumference and skinfold thickness measurements and for dietary intake components. Significance of the differences between the groups was determined by Student-Neuman Keuls post-hoc test. For the above analyses, the results were corrected for age and gender. Independent t-tests were performed to compare the laboratory results for albumin, vitamin $\mathrm{B}_{12}$, carotene, cholesterol, ferritin, hemoglobin, lymphocytes, red blood cells, RBC folate and serum folate, as well as to compare some of the daily dietary intake between the groups. The significance level for all analyses was set at $\mathrm{p}<0.05$.

\section{RESULTS}

1. Do you have difficulty chewing small pieces of beef?

2. Do you difficulty chewing small pieces of chicken?

3. Do you have difficulty chewing ground beef?

4. Do you have difficulty chewing hard, raw vegetables, without cutting them?

5. Do you have difficulty chewing hard, raw fruits, without cutting them (e.g.: apples)?

6. Do you have difficulty chewing hard, raw fruits, after cutting them in quarters?

7. Do you have difficulty chewing peels of hard raw fruits?

8. Do you have difficulty chewing crusted bread?

9. Do you have difficulty chewing nuts and grains?

10. Do you have difficulty chewing with your prosthesis?

11. Do you have to remove one or both of your prostheses in order to eat?

12. Do you have to drink while eating to facilitate swallowing?

13. Do you have to add sauce to your meal to facilitate swallowing?

14. Do you have to soak your food to facilitate chewing and/or swallowing?

15. Is your food choice limited because of your prosthesis?

16. In general, is the food well chewed before being swallowed?

17. Have you eaten beef cut into small pieces?

18. Has it been necessary to ground the beef before eating?

19. Have you eaten chicken cut into small pieces?

20. Has it been necessary to ground the chicken before eating?

21. Has it been necessary to convert meet into puree in order to eat?

22. Have you eaten fresh apples without cutting them?

23. Is it necessary to peel the apples before eating?

24. Is it necessary to cut the apples into quarters in order to chew them?

25. Is it necessary to cut the apples into small pieces in order to chew them?

26. Has it been necessary to convert fruits into puree in order to eat?

27. Have you eaten fresh carrots without cutting them?

28. Is it necessary to cut the carrots into small pieces in order to

Figure 1. English translation of the original French-language version of the Quality of Masticatory Function Questionnaire.
Data analysis showed that the study population was comprised of 31 males (58\%) and 22 females (42\%), with mean age of 53 years (age range: 41-70 years). Twentyfour patients (16 males, 8 females; mean age $=53$ ) wore conventional dentures (CD group) and the other 29 (15 males, 14 females; mean age =52) wore implant-supported overdentures (IP group).

The mean weight was $79 \pm 14 \mathrm{~kg}$ for the CD group and $76 \pm 12 \mathrm{~kg}$ for the IP group $(\mathrm{p}=0.8)$. The difference in mean height values between the groups was not significant $(\mathrm{p}>0.05)(171 \pm 6 \mathrm{~cm}-\mathrm{CD}$ and $168 \pm 9 \mathrm{~cm}-\mathrm{IP})$. There was no significant difference $(\mathrm{p}>0.05)$ between groups for BMI values $(\mathrm{p}=0.54)$. All subjects, except for 2 in the CD group and 3 in the IP group, presented values above the cut off of 22 $\mathrm{kg} / \mathrm{m}^{2}$ for normality, although none of the 5 individuals was 
under $18 \mathrm{~kg} / \mathrm{m}^{2}$.

The mean values obtained from the measurement of body circumference were not significant between the groups $(p>0.05)$. Values for skinfold thickness measurement at the abdominal region for the CD and IP groups were $21 \mathrm{~mm}$ and $27 \mathrm{~mm}$, respectively, this difference being statistically significant $(\mathrm{p}<0.05)$. The $\%$ fat mass derived from the skinfold thickness measurements was similar between the groups.

From the food-frequency questionnaire, the daily dietary intakes were established for each patient, and the mean values were compared between groups. A significant percentage of subjects had an intake of calories higher than the Recommended Dietary Allowances (RDA) of $30 \mathrm{kcal} / \mathrm{kg} /$ day for men and $27 \mathrm{kcal} / \mathrm{kg} /$ day for women: $69 \%$ of subjects in the CD group and $54 \%$ in the IP group were above the RDA's values. All subjects in both groups had intakes of protein above the RDA's values $(0.8 \mathrm{~g} / \mathrm{kg} / \mathrm{day})$. Although the mean values for dietary fiber intake were within the range recommended

Table 1. Mean values for dietary intake according to type of treatment.

\begin{tabular}{|c|c|c|c|}
\hline & $\begin{array}{l}\text { Conventional } \\
\text { denture }\end{array}$ & $\begin{array}{l}\text { Implant-supported } \\
\text { Overdenture }\end{array}$ & \\
\hline & Mean (SD) & Mean (SD) & $p$ \\
\hline Calories & $2562.94(726.75)$ & $2745.45(669.97)$ & 0.34 \\
\hline Proteins (g) & $102.70(32.54)$ & $101.16(21.16)$ & 0.67 \\
\hline $\mathrm{Cal} / \mathrm{kg}$ & $34.12(11.25)$ & $36.45(9.38)$ & 0.58 \\
\hline Prot $/ \mathrm{kg}$ & $1.36(0.42)$ & $1.34(0.27)$ & 0.40 \\
\hline Dietary fibers (g) & $28.91(11.77)$ & $27.03(13.62)$ & 0.59 \\
\hline Vitamin A (IU) & $\begin{array}{c}17946.33 \\
(10265.47)\end{array}$ & $\begin{array}{c}20827.40 \\
(12944.77)\end{array}$ & 0.37 \\
\hline Thiamin- $\mathrm{B}_{1}(\mathrm{mg})$ & $1.96(0.57)$ & $2.03(0.66)$ & 0.71 \\
\hline Ribof. $\mathrm{B}_{2}(\mathrm{mg})$ & $2.56(0.99)$ & $2.58(0.74)$ & 0.92 \\
\hline Niacin Equiv. (mg) & $46.69(13.24)$ & $47.10(12.23)$ & 0.91 \\
\hline Vitamin $\mathrm{B}_{6}(\mathrm{mg})$ & $2.63(0.82)$ & $2.52(0.66)$ & 0.60 \\
\hline Vitamin $B_{12}(\mathrm{mcg})$ & $9.73(8.74)$ & $8.48(6.94)$ & 0.57 \\
\hline Vitamin C (mg) & $248.54(149.71)$ & 190.95 (106.07) & 0.12 \\
\hline Vitamin D (IU) & 204.56 (170.67) & 190.31 (92.09) & 0.70 \\
\hline Vitamin E (IU) & $18.51(7.17)$ & $18.59(7.99)$ & 0.97 \\
\hline Folate (mcg) & $448.14(196.26)$ & $403.64(178.74)$ & 0.40 \\
\hline
\end{tabular}

by the National Cancer Institute (27 to $40 \mathrm{~g} /$ day), roughly half of the patients presented lower values. Values of daily intakes for vitamins $A, B_{1}, B_{2}, B_{6}, B_{12}, C$, $\mathrm{D}, \mathrm{E}, \mathrm{K}$, niacin and folate were all considerably above the RDA's values in both groups. Differences in the means between groups were always nonsignificant (Table 1).

Results from the analysis of the values of blood components are shown in Table 2. Albumin levels fell into the normal range of $38-50 \mathrm{~g} / \mathrm{L}$ for all subjects in the study. Eighteen subjects (75\%) in the CD group and 22 subjects in the IP group (76\%) had cholesterol levels above the limit considered normal $(5.2 \mathrm{mmol} / \mathrm{L}$, if younger than 65 years and $6.2 \mathrm{mmol} / \mathrm{L}$, if older), although the mean values for both groups were under $6.1 \mathrm{mmol} / \mathrm{L}$. The carotene levels were above normal in $13 \%$ of subjects in each group, while $25 \%$ (CD) and $45 \%$ (IP) had red blood cells counts above the normal range. Hemoglobin levels were found to be low in 7 patients (29\%) in the CD group and in 12 patients (21\%) in the IP group. Finally, 21\% (CD) and 33\% (IP) had low ferritine levels. Lymphocyte counts were found to be normal $\left(0.8\right.$ to $\left.4.410^{9} \mathrm{n} / \mathrm{L}\right)$ for all subjects in both groups, as well as lymphocyte counts, vitamin $B_{12}$ levels, serum folate and red blood cell folate. Comparison of the mean values of each group showed no significant differences $(p>0.05)$ for any of the blood component values and all mean values were within the

Table 2. Mean values and standard deviation for blood components according to the treatment group.

\begin{tabular}{lccc}
\hline & $\begin{array}{c}\text { Conventional } \\
\text { denture }\end{array}$ & $\begin{array}{c}\text { Implant-supported } \\
\text { Overdenture }\end{array}$ \\
\cline { 2 - 3 } & Mean (SD) & Mean (SD) & $p$ \\
\hline Albumin $(\mathrm{g} / \mathrm{L})$ & $42.48(4.0)$ & $42.14(2.77)$ & 0.79 \\
Cholesterol $(\mathrm{mmol} / \mathrm{L})$ & $6.09(1.0)$ & $5.87(0.94)$ & 0.67 \\
Carotene $(\mathrm{g} / \mathrm{L})$ & $2.97(1.2)$ & $2.65(1.00)$ & 0.27 \\
RBC $\left(\mathrm{nx} 10^{9}\right)$ & $4.90(0.5)$ & $4.80(0.42)$ & 0.37 \\
Hemoglobin $(\mathrm{g} / \mathrm{L})$ & $145.43(11.5)$ & $142.55(10.80)$ & 0.61 \\
Lymphocytes $\left(\mathrm{nx} 10^{9}\right)$ & $1.62(0.6)$ & $1.60(0.41)$ & 0.76 \\
Ferritin $(\mathrm{g} / \mathrm{L})$ & $139.22(133.0)$ & $131.62(98.40)$ & 0.74 \\
$\mathrm{~B}_{12}(\mathrm{pmol} / \mathrm{L})$ & $295.13(113.73)$ & $259.76(78.79)$ & 0.19 \\
Serum folate $(\mathrm{nmol} / \mathrm{L})$ & $33.30(8.6)$ & $30.72(10.06)$ & 0.40 \\
RBC folate (nmol/L) & $875.70(179.1)$ & $907.48(188.09)$ & 0.52 \\
\hline
\end{tabular}


range considered to be normal.

The results of the QMF showed significant differences $(p<0.05)$ between the groups on the questions referring to the amount of difficulty encountered when chewing pieces of beef, chicken, ground beef, hard raw vegetables, hard raw fruits, fruit with peel, crusted bread and nuts and seeds. A significant intergroup difference was also detected for the sub-item that inquered on how often the prosthesis was the cause for limiting the choice of food, and the sub-item referring to the frequency of having difficulty chewing with the prosthesis (Fig.1). The subsequent items referring to how often meats, raw fruits and vegetables had to be cut down into small pieces or turned into puree in order to be eaten had all demonstrated a inter-group tendency towards significance $(\mathrm{p}<0.1)$. Interestingly, the differences between the groups were not significant $(p>0.3)$ for the questions arguing on the frequency of consumption of meats, raw fruit or vegetables.

\section{DISCUSSION}

This study used a large spectrum of anthropometric and laboratory measurements to determine 1 year after oral rehabilitation if patients who were randomized to implant-supported overdenture treatment had a better diet and nutritional status than those who received conventional denture. In the studied population, a high percentage of people had values above the RDA's values for intake of calories and proteins, and roughly half had lower values for fibers. In a study comparing pretreatment and posttreatment dietary habits between partial removable denture and implantretained partial overdenture wearers similar results were found (14). As for micronutrients, which are present in large amounts in fresh fruits and vegetables, the consumption of subjects of both groups were, on average, above the recommendations. This could mean that, although patients conventional denture wearers have a diminished masticatory ability, they are able to adapt to new ways of chewing and preparing food in order to maintain a good dietary intake, which is in accordance to a recent study (15).

While this may seem predictable, there are conflicting data in the literature. Complete denture wearers have been shown to have significant differences in nutritional indicators when compared to patients that received implant-supported overdentures $(5,6)$.
Approximately two thirds of both groups had higher than normal cholesterol. This could be the result of less than the recommended intakes of fibers by almost half of the sample. The other analyzed blood components were within the recommended levels, indicating that the subjects in the present study had no major nutritional deficiencies, regardless of the type of prosthesis. Although the CD group probably experiences less retention and stability of their prostheses, this does not seem to restrain proper intake.

Although the questionnaire for masticatory function used in this study has not been validated, it did demonstrate the capacity to identify some important inter-group differences. The items concerning difficulty chewing harder foods yielded significant differences. This is probably due to the greater stability and retention of the implant-retained overdenture. These results are supported by studies that compared patients' chewing ability with conventional and implant-retained prostheses $(11,16)$. The questionnaire also showed that conventional denture wearers did not avoid harder foods, even though they reported more chewing difficulties. One could infer from the results of this questionnaire that: 1) conventional dentures were well made and well adapted in order to allow chewing; 2) dietary intake may be influenced by a variety of sociocultural factors; and 3) changes in dietary patterns may not occur solely because the individual's chewing ability improves. Moreover, a recent systematic review on the masticatory efficiency of complete dentures found that the advantages in masticatory performance of implant-supported prosthesis over the conventional denture are restricted to patients with mandibular resorption and/or difficult adaptation to conventional dentures (17). No significant difference was found on the frequency that conventional denture wearers have to cut or chop harder foods (e.g.: apples, carrots, beef), compared to patients with implant overdenture. These differences in food preparation could explain the fact that $\mathrm{CD}$ group subjects eat the same types of foods as IP group subjects, and thus have a very similar nutritional status. However, it is possible that the need to cut or chop certain types of foods cause some inconvenience in life style and, over time, these individuals could start eating less amounts of harder foods, which would reflect in their nutritional parameters. The fact that the group selected for this study was relatively young (mean age of 53 years) and healthy, makes it more difficult to detect differences in 
nutritional status markers. Older adults are more sensitive to reduced dietary intake and thus deficits would be more evident in an older population. It may be that younger, healthier people were elected to participate in this trial. This study did not assess the subjective performance with the original dentures, nor the pretreatment nutritional status of subjects. Hence, there is no indication of how much intra-individual change occurred with implant-supported or new conventional dentures. It would have been interesting to analyze these potential changes, especially because the treatments were assigned at random.

Within the limitations of this study, the obtained results showed that, no significant differences were observed in the nutritional status between patients who had been rehabilitated with either conventional dentures or implant-supported overdentures 1 year previously. Despite this, conventional denture wearers found chewing harder foods to be more difficult. However, as no differences were noted in the subjects' nutritional condition, it is likely that the reportedly higher chewing difficulty did not refrain them from eating harder foods.

\section{RESUMO}

O uso de implantes para suportar próteses em pacientes edêntulos completos causa uma melhora significativa na performance mastigatória desses indivíduos. Contudo, a influência desse benefício no estado nutricional do paciente ainda não está completamente estabelecida. Esse estudo avaliou o estado nutricional de pacientes desdentados completos reabilitados com próteses totais convencionais (grupo $\mathrm{CD}$ ) ou com próteses totais implanto-suportadas (grupo IP) na mandíbula. Foram coletados dados sobre composição corporal e uma amostra de sangue para análise. Os participantes responderam a um questionário sobre freqüência alimentar (QFA) e outro sobre habilidade mastigatória e método de preparo dos alimentos (QMF). A amostra foi composta de 53 participantes selecionados a partir de um estudo randomizado, sendo 58\% homens e $42 \%$ mulheres, com idade média de 53 anos. Os indicadores de composição corporal se encontraram dentro da normalidade e sem diferenças significativas ( $\mathrm{p}>0.05)$. O grupo CD obteve valores significativamente diferentes para itens do QMF sobre dificuldade de mastigar $(\mathrm{p}<0.05)$. Os dados do QFA e o resultado do exame de plasma estavam dentro dos níveis normais, e os valores entre os grupos foram semelhantes ( $p>0.05$ ). Embora os participantes que receberam prótese total convencional tenham relatado maior dificuldade de mastigar alimentos duros, os dois grupos apresentaram estados nutricionais semelhantes.

\section{REFERENCES}

1. National Center for Health Statistics. Health, United States, 2006. 293. 2006. Hyattsville, MD, U.S. Government Print- ing Office. 2006. Ref Type: Report.

2. Brodeur JM, Benigeri M, Naccache H, Olivier M, Payette M. Trends in the level of edentulism in Quebec between 1980 and 1993. J Can Dent Assoc 1996;62:159-166.

3. Millar WJ, Locker D. Edentulism and denture use. Health Rep 2005; 17:55-58.

4. Horwath CC. Chewing difficulty and dietary intake in the elderly. J Nutr Elder 1989;9:17-24.

5. de Oliveira TR, Frigerio ML. Association between nutrition and the prosthetic condition in edentulous elderly. Gerodontology 2004;21:205-208.

6. Morais JA, Heydecke G, Pawliuk J, Lund JP, Feine JS. The effects of mandibular two-implant overdentures on nutrition in elderly edentulous individuals. J Dent Res 2003;82:53-58.

7. Bates JF, Elwood PC, Foster W. Studies relating mastication and nutrition in the elderly. Gerontol Clin (Basel) 1971;13:227-232.

8. Mobley CC. Nutrition issues for denture patients. Quintessence Int 2005;36:627-631.

9. Berg E. Acceptance of full dentures. Int Dent J 1993;43:299306.

10. Awad MA, Feine JS. Measuring patient satisfaction with mandibular prostheses. Community Dent Oral Epidemiol 1998;26:400-405.

11. Awad MA, Lund JP, Dufresne E, Feine JS. Comparing the efficacy of mandibular implant-retained overdentures and conventional dentures among middle-aged edentulous patients: satisfaction and functional assessment. Int $\mathrm{J}$ Prosthodont 2003;16:117-122.

12. Willett WC, Sampson L, Stampfer MJ, Rosner B, Bain C, Witschi $J$ et al.. Reproducibility and validity of a semiquantitative food frequency questionnaire. Am J Epidemiol 1985;122:51-65.

13. Awad MA, Lund JP, Shapiro SH, Locker D, Klemetti E, Chehade A et al.. Oral health status and treatment satisfaction with mandibular implant overdentures and conventional dentures: a randomized clinical trial in a senior population. Int J Prosthodont 2003;16:390-396.

14. Garrett NR, Kapur KK, Hamada MO, Roumanas ED, Freymiller E, Han $\mathrm{T}$ et al.. A randomized clinical trial comparing the efficacy of mandibular implant-supported overdentures and conventional dentures in diabetic patients. Part II. Comparisons of masticatory performance. J Prosthet Dent 1998;79:632-640.

15. Ellis JS, Thomason JM, Jepson NJ, Nohl F, Smith DG, Allen PF. A randomized-controlled trial of food choices made by edentulous adults. Clin Oral Implants Res 2008;19:356-361.

16. Boerrigter EM, Geertman ME, Van Oort RP, Bouma J, Raghoebar GM, van Waas MA et al.. Patient satisfaction with implant-retained mandibular overdentures. A comparison with new complete dentures not retained by implants- A multicentre randomized clinical trial. $\mathrm{Br} \mathrm{J}$ Oral Maxillofac Surg 1995;33:282-288.

17. Fueki K, Kimoto K, Ogawa T, Garrett NR. Effect of implantsupported or retained dentures on masticatory performance: a systematic review. J Prosthet Dent 2007;98:470-477.

Accepted April 1, 2008 